\title{
FOREIGN TRADE IN AGRICULTURAL PRODUCTS BETWEEN THE REPUBLIC OF SERBIA AND THE REPUBLIC OF KAZAKHSTAN - A DECADE SINCE THE SIGNING OF THE FREE TRADE AGREEMENT
}

\author{
Milica Simić* \\ ALFA BK University, Belgrade, Republic of Serbia \\ Biljana Stankov \\ Novi Sad School of Business, Novi Sad, Republic of Serbia
}

\begin{abstract}
Modern international economic relations, among other things, are characterized by establishing bilateral and multilateral cooperation between countries in order to liberalize trade relations. The implementation of reached free trade agreements affects economic trends in the signatory countries, the intensification of their foreign trade as wll as the increase in the attractiveness of countries as investment destinations. From 2000 onwards, Serbia has signed several free trade agreements with European countries and the United States. Ten years ago, a free trade agreement was signed with the Republic of Kazakhstan in order to encourage the development of mutual trade and economic relations, accelerate economic development, improve living and working conditions, increase employment and establish fair competition between economic entities from Serbia and Kazakhstan. The subject of the mentioned trade relations are also agri-food products, whose production in Serbia is supported by an excellent raw material base, and has always been a part of national tradition and culture. The reserch subject of this paper is foreign trade of agricultural products between Serbia and Kazakhstan with regard to free trade agrrements. The research aim is to determine the differences in the movement of exports and imports between the mentioned countries in the period before and after the signing of the free trade agreement.
\end{abstract}

Keywords: Free Trade Agreement, Republic of Serbia, Republic of Kazakhstan, foreign trade, agricultural products

JEL classification: F18, F53, Q17

*milica.simic@alfa.edu.rs 


\title{
SPOLJNOTRGOVINSKA RAZMENA POLJOPRIVREDNIH PROIZVODA IZMEĐU REPUBLIKE SRBIJE I REPUBLIKE KAZAHSTAN - DECENIJA OD POTPISIVANJA SPORAZUMA O SLOBODNOJ TRGOVINI
}

\begin{abstract}
Sažetak: Savremene međunarodne ekonomske odnose, između ostalog, karakteriše $i$ uspostavljanje bilateralne $i$ multilateralne saradnje među državama u cilju liberalizacije trgovinskih odnosa. Primena sklopljenih sporazuma o slobodnoj trgovini utiče na privredna kretanja u zemljama potpisnicama, zatim na intenziviranje njihove spoljnotrgovinske razmene $i$ na povećanje atraktivnosti zemalja kao investicionih destinacija. Od 2000. godine pa nadalje, Srbija je potpisala nekoliko sporazuma o slobodnoj trgovini sa evropskim zemljama $i$ SAD. Pre deset godina potpisan je $i$ sporazum o slobodnoj trgovini sa Republikom Kazahstan kako bi se podstakao razvoj međusobnih trgovinsko-ekonomskih odnosa, ubrzao ekonomski razvoj, poboljšali uslovi života $i$ rada stanovništva, povećala zaposlenost $i$ uspostavila lojalna konkurencija između privrednih subjekata iz Srbije i Kazahstana. Predmet pomenutih trgovinskih odnosa su $i$ poljoprivredno-prehrambeni proizvodi, čija je proizvodnja u Srbiji podržana odličnom sirovinskom osnovom, a oduvek je predstavljala $i$ deo nacionalne tradicije $i$ kulture. Predmet istraživanja ovog rada jeste spoljnotrgovinska razmena poljoprivrednih proizvoda između Srbije $i$ Kazahstana u kontekstu sporazuma o slobodnoj trgovini. Cilj istraživanja se odnosi na utvrđivanje razlika u kretanju izvoza $i$ uvoza među pomenutim zemljama u periodu pre $i$ nakon potpisivanja sporazuma o slobodnoj trgovini.
\end{abstract}

Ključne reči: Sporazum o slobodnoj trgovini, Republika Srbija, Republika Kazahstan, spoljnotrgovinska razmena, poljoprivredni proizvodi

\section{INTRODUCTION}

In the conditions of increased globalization, regional and subregional cooperation between countries, which is based on the fulfillment of common interests and the satisfaction of individual needs, has become increasingly important. Modern international economic relations are clearly recognizable by the phenomenon of regional integration. This is also supported by Knežević and Pavlović (2014) who point out that one of the most significant tendencies in the development of the modern world is the growth of economic integration 
processes and the establishment of a large number of trade blocs of universal and regional character. Growing interdependence at the global level and the achieved level of development of the economy and technology have imposed an even greater need to improve and deepen the existing, classic forms of international economic integration. Lapenko (2018) emphasizes that despite different levels of integration and the degree of economic influence, regional integration organisations already play the role of independent actors in the world economy. In this context, Vasily and Ivolga (2013) point out that in addition to the fact that trade integration in certain circumstances can cause certain harmful effects, it can certainly bring about certain benefits.

Visible investments in the Serbian economy began only after 2000, and since then significant variations in foreign investment trends could be noticed. These variations have occured primarily due to the impact of the global economic and financial crisis, as well as the announcement of Serbia's accession to the EU and gaining candidate status, signed free trade agreements, features of the business environment, implementation of institutional reforms and attraction of investments through privatization processes. Bjelić and Dragutinović Mitrović (2012) support the above-mentioned stance and point out that since 2000, the Republic of Serbia (hereinafter Serbia) has reappeared as one of the participants in international trade. The year of 2000 was also marked by the intensification of foreign trade relations between Serbia and Russia by signing a free trade agreement, which provided Serbia with a privileged position in relation to other European countries. Liberalization of regional trade relations in Southeast Europe began next year with signing the Memorandum of Understanding on Trade Liberalization and Facilitation under the auspices of the Stability Pact for South-Eastern Europe. In the mentioned process, Serbia was one of the signatories of more than 30 agreements on international liberalization of trade in industrial and agricultural products. The improvement of Serbia's foreign trade position at the international level and its attractiveness as an investment destination was encoraged by signing the Stabilization and Association Agreement and the Interim Agreement on Trade with the European Union (hereinafter EU) in 2008, the Free Trade Agreement with the member states of European Free Trade Association (hereinafter EFTA), then with Belarus and Turkey in 2009, next year with Kazanstan, and joining the Generalized System of Preferences with the United States in 2018. On the other hand, Bartlett (2009) emphasizes that the Balkan states, including Serbia, are involved in a very complex and contradictory process of simultaneous regional integration and disintegration. The key instrument of regional integration is the network of bilateral trade agreements concluded by the mentioned countries under the auspices of the Stability Pact for South-Eastern Europe and the CEFTA agreement. 
89 | FOREIGN TRADE IN AGRICULTURAL PRODUCTS BETWEEN THE REPUBLIC OF SERBIA AND THE REPUBLIC OF KAZAKHSTAN - A DECADE SINCE THE SIGNING OF THE FREE TRADE AGREEMENT

Božić and Nikolić (2013) claim that the strengthening of integration processes in the global economy is a trend that largely determines the characteristics of overall international trade, especially trade in agricultural and food products. Research on trends in trade in agricultural and food products in some regions of the world indicates the existence of significant differences in the level of intraindustry trade. Bojnce (2001) points out that the mentioned differences are most noticeable in Europe. Agricultural products have traditionally had a significant presence in the export structure of the Serbian economy. In the conditions of the economic crisis, the agricultural sector of Serbia has shown the highest degree of resistance in production and exports during the past decades, and has contributed to achieving the country's foreign trade balance and reducing the negative balance. Research on foreign trade of agricultural products, especially in the conditions of new economic integrations and regional connections among countries, is becoming a very current topic in the scientific and professional literature.

In 2010, Serbia signed a free trade agreement with Kazakhstan, thus establishing a free trade regime in mutual trade in goods and services, in accordance with national legislation, the provisions of this agreement and WTO rules. The research subject of this paper is the foreign trade of agricultural products between Serbia and Kazakhstan before and after the signing of the free trade agreement. The paper will pay special attention to the economic circumstances in Serbia, the potential of agricultural production and trade, the challenges posed by the provisions of the signed free trade agreement with Kazakhstan and the analysis of quantitative trends in imports and exports between Serbia and Kazanstan in 2004-2019, that is, before and after the signing of the free trade agreement.

\section{ECONOMIC ENVIRONMENT IN THE REPUBLIC OF SERBIA}

The global financial crisis has pointed to many structural weaknesses in Serbia's economic growth model and at the same time encouraged the solution of fiscal problems and the acceleration of the unfinished transition from a centrally planned to a market economy structure. The rapid economic growth recorded in the country between 2001 and 2008 was largely supported by an increase in domestic consumption and led to significant internal and external imbalances, so that it proved completely unsustainable. Serbia has gone through a truly dramatic period of change, adapting to extremely rapid changes in the political 
and economic environment. In the future, structural reforms are expected to continue and special attention will be paid to public administration reforms, solving problems related to public finances and transforming the social sector, accompanied by ongoing negotiations and additional efforts in the process of joining the European Union. According to the World Bank data, 6.98 million people lived in Serbia in 2018, and GDP amounted to US \$ 50.64 billion. In the same year, the dominance of imports over exports of products and services was recorded, i.e. the share of exports in GDP was 50\%, while imports reached a share of 59\%. As Stanojević and Jovancai (2015) state, the key features of the current trade relations of Serbia with foreign countries are a high and growing foreign trade deficit and a very small number of export partners. For a long time now, Serbia has been achieving almost all of its exports on the markets of only a few, mostly neighboring, countries, and the need for geographical diversification of exports and finding new export markets has become widely perceived.

Some of the goals that should be pursued soon are related to ensuring economic and financial stability, stopping the accumulation of public debt, creating a favorable environment that would support economic recovery a well as increasing economic growth rate while encouraging employment and raising living standards. These goals will be achieved primarily through the implementation of fiscal consolidation measures, accelerating structural reforms and encouraging the inflow of foreign direct investment (FDI). It can be said that Serbia is competing with other countries in the SEE and CEE region in attracting as much foreign investment as possible, primarily by establishing liberal FDI laws, reducing corporate income taxes and removing trade barriers and investment bans. Cheng and Kwan (2000) point out that many countries view attracting FDI as a very important element in their economic development strategies because they are considered to be a combination of capital, technology, marketing and management.

Owing to its many advantages such as favorable geographical strategic position, availability of natural resources, liberal labor laws, favorable employment and dismissal policies, friendly FDI laws, low start-up costs, benefits resulting from signed multilateral and bilateral free trade agreements as well as candidate status for EU membership, Serbia over time has become a very attractive investment destination (Stankov, Markov \& Milošević, 2017). 
91 | FOREIGN TRADE IN AGRICULTURAL PRODUCTS BETWEEN THE REPUBLIC OF SERBIA AND THE REPUBLIC OF KAZAKHSTAN - A DECADE SINCE THE SIGNING OF THE FREE TRADE AGREEMENT

\section{CONTRIBUTION OF THE FREE TRADE AGREEMENT TO THE ATTRACTIVENESS OF THE REPUBLIC OF SERBIA AS AN INVESTMENT DESTINATION}

During 2012, Serbia was marked as a very attractive investment destination, one of the leaders in the CEE region in terms of attracting production-oriented FDI as well as those that create new jobs. In addition to the available qualified and cheap labor, competitive business costs, financial incentives and impetus, a very important benefit for foreign investors comes from the duty-free treatment provided by numerous trade agreements to which Serbia is one of the signatories. In this context, Stankov (2017) emphasizes that the Stabilization and Association Agreement was signed in April 2008, by which Serbia undertook the obligation to establish a free trade zone and harmonize its own legislation with the acquis communautaire. At the same time, the Interim Agreement on Trade was signed, which envisages the gradual establishment of free trade in industrial and agricultural products in the next six years, with special emphasis being paid on the reduction or abolition of customs duties on certain types of products. Observing Serbia's foreign trade position, Jelisavac Trošić, Stojanović Višić and Petrović (2018) claim that it can become a "production hub" for duty-free exports to markets involving more than a billion people, including the EU, Russia, the USA, Kazakhstan, Turkey, Southeast Europe, EFTA members and Belarus.

Serbia is one of the very few countries in Europe that signed a Free Trade Agreement with Russia in 2000 that has provided for exemption from customs duties in certain circumstances and under prescribed conditions. In order to improve and deepen trade cooperation, Serbia signed free trade agreements with Belarus and Turkey in 2009 and with Kazakhstan in 2010, thus obtaining exemption from customs duties or the use of customs preferences under strictly prescribed conditions (Stankov, Roganović \& Marjanski Lazić, 2016). Using the gravity model, Baier and Bergstrand (2007) analyzed changes in foreign trade and concluded that free trade agreements concluded between certain countries significantly have affected the growth of trade in the signatory countries.

Serbia's foreign trade with the United States is largely regulated by the Generalized System of Preferences, which was approved in July 2005. Through this program, the United States grants trade preferences to other countries, its 
trading partners, in order to stimulate their economic development and provides preferential duty-free treatment for most final products and semi-finished products, as well as certain agricultural products and raw materials originating from those countries. It should be emphasized that no country with which free trade agreements have been signed so far has given Serbia such benefits as the EU has given it. The EU, as the most important trade partner of Serbia, participates with about $60 \%$ in the total trade exchange of Serbia, while, for example, the participation of Russia is about 9\%, and China's participation is approximately 4.4\% (Grandov, Stankov \& Roganović, 2014). In addition to being the main trade partner, the EU is also Serbia's main investment partner.

In addition to the above, foreign investors are particularly interested in all other trade benefits and facilitations provided to them in Serbia, which are realized on the basis of signed Free Trade Agreements between Central European countries (CEFTA) and Free Trade Agreements with with the member states of European Free Trade Association (EFTA). Under the auspices of the Stability Pact for South-Eastern Europe, the process of liberalizing the region's market began in 2001 with the signing of a Memorandum of Understanding on Trade Liberalization and Facilitation. On that occasion, a number of agreements on mutual liberalization of trade in agricultural and industrial products were signed between the countries of Central and Southeast Europe (Albania, Bosnia and Herzegovina, Bulgaria, Croatia, Macedonia, Moldova, Romania, Serbia and Montenegro). CEFTA provides market expansion for all products but also trade under the same conditions for all producers, expands and modernizes the domain of free trade, opens a larger market for trade and investment and develop institutions responsible for management in this area. The agreement envisages the liberalization of public procurement and the attraction of investments in the signatory countries, and also increases the chance of entering European markets under preferential, privileged treatment. After Bulgaria, Romania and Croatia joined the EU, the benefits provided by this agreement ceased to apply to them; however, they continued to apply to remaining signatory countries. In December 2009, the Government of Serbia signed a free trade agreement with EFTA member states (Iceland, Liechtenstein, Norway and Switzerland) and thus took another step towards improving Serbia's position in the international trade system. In this way, producers and exporters from Serbia were not only enabled to export duty-free products to a market of nearly 13 million inhabitants, but were pesented with the oportunity to attract new foreign investment, given that EFTA member states have so far invested significant funds in the Serbian economy that reach an amount of close to two billion euros. 
93 | FOREIGN TRADE IN AGRICULTURAL PRODUCTS BETWEEN THE REPUBLIC OF SERBIA AND THE REPUBLIC OF KAZAKHSTAN - A DECADE SINCE THE SIGNING OF THE FREE TRADE AGREEMENT

It must be mentioned that, in addition to the above, Serbia has also developed foreign trade relations with the countries of Eurasia. Đukanović and Gajić (2012) state that in the geopolitical sense, the term Eurasia is most often used as a synonym for the post-Soviet space, i.e. the territory to which the independent states have belonged after the collapse of the Soviet Union. The agreement on the free trade zone between the Eurasian Economic Union (EAEU) and the Republic of Serbia envisages a high degree of liberalization of mutual trade, which, among other things, is reflected in the non-collection of customs duties on almost $99 \%$ of customs tariff products. Among the EAEU member states, Russia is certainly the most important economic and trade partner of Serbia. The results of the research conducted by Miljkovic (2018) indicate that, after Russia, Kazakhstan is in second place, while symbolic economic cooperation is being achieved with other countries of this integration. The mentioned author also concludes that the preferential trade agreements signed between the Republic of Serbia and the EAEU member states have not given their full economic effect so far. Serbia hardly uses the benefits provided by the free trade agreement with Kazakhstan signed ten years ago. The future of this agreement, among other things, depends on Serbia's progress towards EU membership. Rapaić and Dabić (2013) point out that the differences in the level of customs burden in the Republic of Serbia and the EU are very visible, and that with EU membership, Serbian goods will lose preferential treatment in Russia, Kazakhstan, Belarus and the USA.

\section{CHALLENGES OF THE FREE TRADE AGREEMENT BETWEEN THE REPUBLIC OF SERBIA AND THE REPUBLIC OF KAZAKHSTAN}

Kazakhstan is a country in the Caspian Basin that has a much wider national market compared to Serbia, given that according to the World Bank in 2018, Kazakhstan had a population of 18.28 million (almost 3 times higher than Serbia), while GDP amounted to US \$ 179.34 billion (as much as 3.5 times more than in Serbia). In the same year, the dominance of exports over imports of products and services was recorded, given that exports amounted to $38 \%$ of GDP and imports to 26\% of GDP. At the beginning of the 1990s, Kazakhstan became an independent state and began the process of economic transformation and transition from a centrally planned to a market economy. This country is considered the most attractive destination for foreign investors in Central Asia. 
In that context, Kunekova (2015) points out that as much as $70 \%$ of the inflow of foreign investments in Central Asia was realized in Kazakhstan.

The development of the national economy is mainly based on the use of extensive natural resources. Kazakhstan is one of the leading countries in oil production and exports in the region. The share of oil in the total exports of Kazakhstan used to be around 15\%, while after the implemented reforms supported by foreign investments, that share increased to almost $60 \%$. In the given context, Stanojević and Jovancai (2015) point out that due to the position of this country on the transit oil and gas pipeline, oil exports mainly take place towards the Russian Federation. The service sector contributes more than $60 \%$ to GDP, followed by the industrial sector and then agriculture. In line with the above, Eren (2012) notes that the share of agriculture in the GDP of this country is declining with a simultaneous increase of the share of the industrial and service sectors in GDP.

Kazakhstan is dominated by the production of machinery, especially agricultural machinery, then electric motors and construction materials, and as much as half of total exports are directed to EU countries. Exploring the competitive advantages of Kazakhstan's foreign trade, Bozduman and Erkan (2019) called this country a "rising star" of Central Asia. The mentioned authors concluded that Kazakhstan has competitive advantage in the export of oil and oil derivatives, natural gas, non-ferrous metals, unorganic chemical products, iron and steel, raw and processed leather and fur, etc. Imanberdiev, Kasimov and Turiginbaeva (2001) investigated the impact of technological advantages, especially innovation, on the economic development of Kazakhstan, and concluded that the global picture of innovation processes in the country was mainly defined by the metallurgy sector (almost 85\%), followed by construction, chemical industry and mining, and that agriculture in this context emerged as a complete "outsider".

Kazakhstan is one of the world's largest landlocked countries, which certainly affects its export potential and in a sense limits its access to global markets. In this context, Nordas, Pinali and Grosso (2006) point out that many bilateral relations are characterized by suspicion, mistrust and lack of cooperation on transit issues. Kazakhstan has significant potential for exporting processed dairy products to neighboring countries, but a number of market barriers reduce real market opportunities. However, despite the mentioned limitations, Immamverdiyev (2017) claims that in the whole of Central Asia only Kazakhstan has comparative advantage in wheat exports which are directed in three key directions: Iran, Azerbaijan, Georgia and Turkey, then Central Asian countries and European countries. 
95 | FOREIGN TRADE IN AGRICULTURAL PRODUCTS BETWEEN THE REPUBLIC OF SERBIA AND THE REPUBLIC OF KAZAKHSTAN - A DECADE SINCE THE SIGNING OF THE FREE TRADE AGREEMENT

The Free Trade Agreement between the Republic of Serbia and the Republic of Kazakhstan was signed on October 7, 2010, and came into force on January 1, 2011. The objectives of this agreement are: to expand and encourage mutual trade and economic relations aimed at accelerating the economic development of these countries, improving the living and working conditions of their citizens, increasing employment in the field of production, establishing production and financial stability, providing conditions for fair competition between economic entities from the signatory countries. Serbia and Kazakhstan, in accordance with national legislation, the provisions of this agreement and WTO rules, have established a free trade regime in mutual trade in goods and services.

In order to implement the provisions of this Agreement, the signatory countries may conclude international agreements on mutual recognition of test results, certificates of conformity or other documents, which directly or indirectly relate to products that are the subject of their mutual trade. Products exempted from the free trade regime when exported from Serbia to the customs territory of Kazakhstan are: meat, cheese, white sugar, cigarettes, sparkling wine, undenatured ethyl alcohol, pneumatic tires, cotton fabrics, compressors for refrigeration equipment, motor vehicles (Development Agency of Serbia RAS). On the other hand, products that are exempted from the free trade regime when imported into the customs territory of Serbia from Kazakhstan are: cheese, white sugar, cigarettes, undenatured ethyl alcohol, pneumatic tires, trucks, tractors, motor vehicles. The conditions and methods for determining the conformity of products with technical normative acts shall be determined by the authorized bodies of the Contracting States in accordance with the national legislation of the importing country and the provisions of the WTO Agreement on Technical Barriers to Trade (International Agreements No. 11/10, Article 7). The procedure of monitoring the implementation of this agreement is entrusted to the Commission consisting of representatives of authorized bodies from both countries. The Commission meets once a year, alternately in Serbia and Kazakhstan, and in addition to making recommendations related to achieving the objectives of the agreement, it also considers the results of cooperation provided for in this agreement. The Commission recommends amendments to the agreement and may, if necessary, sets up sub-commissions and working groups to facilitate the achievement of the envisaged objectives. 
Table 1

Movements of the export and import values of the Republic of Serbia and the Republic of Kazakhstan by SITC sectors in thousands of USD

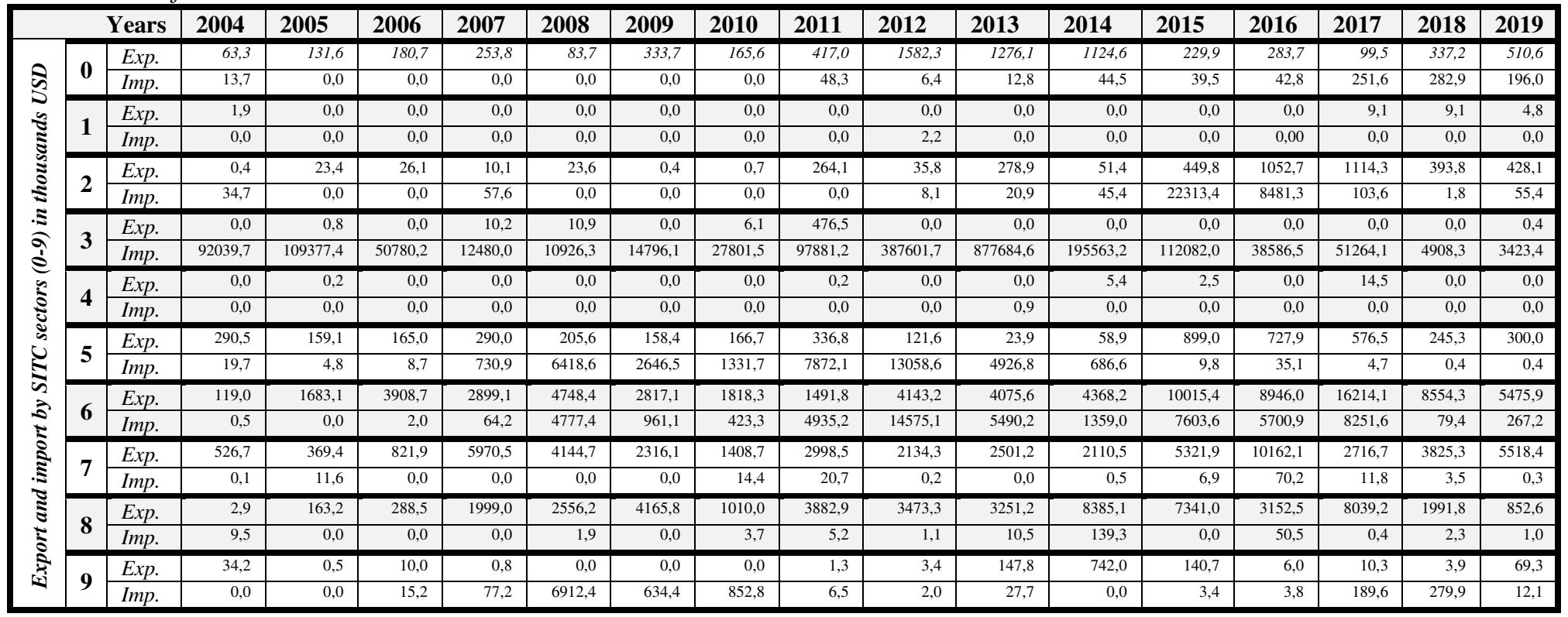

Note. Adapted according to data of Statistical Office of the Republic of Serbia

\section{Legend:}

0 - Food and live animals

$1-$ Beverages and tobacco

2 - Crude materials, inedible, except fuels

3 - Mineral fuels, lubricants and related materials

4 - Animal and vegetable oils, fats and waxes
5 - Chemicals and related products, not elsewhere specified

6 - Manufactured goods classified chiefly by material

7 - Machinery and transport equipment

8 - Miscellaneous manufactured articles

9 - Unmentioned products in SMTK

SITC - Standard International Trade Classification 
97 | FOREIGN TRADE IN AGRICULTURAL PRODUCTS BETWEEN THE REPUBLIC OF SERBIA AND THE REPUBLIC OF KAZAKHSTAN - A DECADE SINCE THE SIGNING OF THE FREE TRADE AGREEMENT

Examining the value of exports and imports of Serbia and Kazakhstan, by economic sectors in accordance with SITC (Table 1), it can be concluded that in the period from 2004 to 2019 the value of exports amounted to 202,355.2 thousand USD, while imports reached almost 11 times higher value (2,220,888.7 million USD). During the observed period, Serbia imported the most mineral fuels from Kazakhstan, the value of which accounted for as much as $94 \%$ of the value of total imports, while various finished products, machines and transport devices dominated the value of exports from Serbia to Kazakhstan.

Food and live animals as a segment of agricultural production, during the observed period, had a minimal share in the foreign trade of these countries. Namely, the export of food and live animals from Serbia to the customs territory of Kazakhstan made only $3.5 \%$ of the total export value, while on the other hand the import of the mentioned products from Kazakhstan to Serbia hardly existed, it amounts to $0.04 \%$ of the total import realized among these countries. during the observed period. When comparing the realized values of exports and imports of these products, it can be noticed that the export of food and live animals from Serbia was 7.5 times higher than the value of imports of the same products from Kazakhstan to Serbia. In order to determine the intensity of foreign trade activities before and after the signing of the free trade agreement between Serbia and Kazakhstan, Table 1 shows the trends of exports and imports in the six-year period from 2004 to 2009 (before signing the agreement) and in the period from 2010 to 2015 (after signing the agreement).

Based on the data of the Statistical Office of the Republic of Serbia, it can be concluded that the total value of imports from Kazakhstan to Serbia, before signing the agreement, amounted to $313,802.4$ million USD, while after signing the agreement, imports reached 1,784,523.4 million USD, or it was 5.7 times higher than in the previous period. When it comes to the total value of exports from Serbia to the customs territory of Kazakhstan, the situation is different. Namely, it was previously stated that exports were significantly lower than imports, and in the period before the signing of the agreement the value of total exports reached 41,969.2 million USD (7.5 times less than the value of imports), while after the signing of the agreement exports were slightly increased and amounted to 78,740.1 million USD, i.e. the value of total exports after the signing of the agreement increased 1.9 times compared to the previous period. In the period before the signing of the free trade agreement between the 
analyzed countries, the value of exports was 7.5 times lower than the value of imports, while in the period after the signing of the agreement this difference was further deepened, and the value of exports became as much as 22.7 times lower than the value of imports.

\section{POTENTIALS OF PRODUCTION AND TRADE IN AGRICULTURAL PRODUCTS OF THE REPUBLIC OF SERBIA}

Agriculture and food industry in Serbia are especially attractive economic sectors that are also very attractive to foreign investors, which is clearly reflected in the value of invested funds, as well as in the number of realized investment projects. The reasons for that are an excellent raw material base, signed free trade agreements, a long tradition in food production, strong regional brands of agricultural and food products, etc. Jelisavac Trošić, Stojanović Višić and Petrović (2018) point out that in the past, Serbia was a predominantly agricultural country. At the beginning of the eighties of the twentieth century, there was a significant growth of agricultural production in Serbia, which at the end of the eighties began to stagnate, only to fall sharply during the nineties. Then came the negative trend in the production of almost all agricultural products. Bogdanova and Rodic (2014) believe that the decline in agricultural production was due to institutional disruptions, reduced subsidies and market collapse, while Van Berkum and Bogdanov (2012) point out that the influence of several factors, of both subjective and objective nature, caused Serbia's failure to exploit the competitive advantages it possessed over other countries in transition. In Serbia, reforms in the agricultural sector began almost a decade later than in other countries in transition. Šabić et al. (2012) note that in the second half of 1999, a certain recovery of the production sector was recorded in Serbia, and that the structure of production was changed in the direction of reducing the share of industry and increasing the share of agriculture, public services and energy. In the field of agriculture, aspirations were aimed at strengthening the institutional sector, improving legislative solutions, reducing the presence of the gray economy and the stability of the market for basic agricultural products. However, despite the fact that customs and non-customs barriers have been significantly reduced in Serbia, Kuzmanović and Sanfey (2014) point out that the agricultural sector still remains quite protected, primarily by high import duties.

The Republic of Serbia is a country where agriculture and food production have always been part of the culture and rich tradition. About 5 million hectares of agricultural land (of which $60 \%$ is arable land) and very favorable climatic conditions, provide a sure impetus to agricultural development. The food industry is one of the strongest sectors of the Serbian economy. According to 
99 | FOREIGN TRADE IN AGRICULTURAL PRODUCTS BETWEEN THE REPUBLIC OF SERBIA AND THE REPUBLIC OF KAZAKHSTAN - A DECADE SINCE THE SIGNING OF THE FREE TRADE AGREEMENT

the RAS (Development Agency of Serbia), there is a surplus in the trade balance of agricultural products of the Republic of Serbia, which in 2018 reached as much as 1.1 billion euros, with export growth of $1.1 \%$ compared to the previous year (RAS, Invest in Serbia Agri-Food).

Table 2

Production of major types of fruits and vegetables in the Republic of Serbia during 2019

\begin{tabular}{|l|c||l|c|}
\hline \multicolumn{1}{|c|}{ Fruit } & Quantity (Tones) & \multicolumn{1}{c|}{ Vegetables } & Quantity (Tones) \\
\hline Plum & 558.930 & Potato & 702.086 \\
\hline Apple & 499.578 & Cabbage & 178.308 \\
\hline Grape & 163.516 & Melon and Waterm. & 163.483 \\
\hline Raspberry & 120.058 & Pepers ("Paprika") & 118.256 \\
\hline Sour Cherry & 96.965 & Tomato & 111.639 \\
\hline Pear & 54.859 & Cucumber & 29.711 \\
\hline Peach & 48.204 & Onion & 29.588 \\
\hline Strawberry & 19.608 & Peas & 25.612 \\
\hline
\end{tabular}

Note. Adapted according to data of Statistical Office of the Republic of Serbia.

During 2019, the structure of fruit production was dominated by plums, then apples and grapes, and raspberries and cherries. As for the production of vegetables in the same year, potatoes were produced the most, much more than other vegetable crops, followed by cabbage, melons and watermelons, peppers and tomatoes. According to the Development Agency of Serbia (RAS) data, during 2018, the export of Serbian fruit amounted to 520.5 million euros, and Serbia was then the leading exporter of apples from Europe to the Russian Federation. The exceptional quality of the fruit, semi-finished products and final products from raspberries, blackberries and other berries provides Serbia with a leading position among exporters in Europe. Serbia is the dominant supplier of frozen fruit in Austria, Russia and Germany. Foreign investors engaged in the production of various fruit products are very interested in investing in the Serbian economy because that is where they can find a quality raw material base.

Thanks to the favorable climatic conditions for growing vegetables, Serbia is becoming one of the leading suppliers of vegetables in Southeast Europe. During 2018, mostly vegetable crops were produced, such as: potatoes, cabbage, melons and watermelons, peppers, tomatoes, cucumbers, onions and 
peas. Among the mentioned types of vegetables, the most exported are paprika, cabbage, tomatoes and potatoes.

Livestock in Serbia has a very long tradition, especially the production of fresh and smoked pork and beef, as well as poultry. Serbian meat and processing companies have a very strong position in the CEFTA market. The production of fresh and pasteurized milk of high quality fully satisfies national needs, but a certain amount is also exported to the markets of neighboring countries, mainly Montenegro and Bosnia and Herzegovina.

By adequately exploiting the available natural resources, Serbia can ensure the growth of productivity and competitiveness of the agricultural sector in the future. In the current circumstances, agriculture makes a significant contribution to the value of GDP, affects employment and job creation. Bogdanova and Ristic (2014) point out that the contribution of agriculture to the trade balance of the Republic of Serbia is evident and that the share of the agricultural sector in total exports is about $20 \%$.

The key changes in the dynamics and structure of trade in agricultural and food products on the international market followed the implementation of international integration processes, Serbia's membership in CEFTA and the signing of the Stabilization and Association Agreement with the EU. In this context, Božić and Nikolić (2013) point out that the liberalization of trade, which has occurred, as well as the growing international market of agricultural and food products are an exceptional opportunity to promote exports of these products from the Republic of Serbia, but on the other hand, the opening of the market can cause a serious threat to certain branches of agriculture and bring about changes in the production structure. Dealing with the analysis of intraindustry trade by groups of agricultural and food products, Božić and Nikolić (2013) state the existence of significant differences. Namely, the mentioned authors conclude that within the total foreign trade of agricultural products from the Republic of Serbia, intra-industry trade is more represented in products with a higher level of processing, where there is a significant degree of differentiation, while significantly lower level of intra-industry trade is characteristic of product groups with a lower level of processing.

By applying the gravity model of panel data, Matkovski, Lovre and Zekić (2017) covered $97.3 \%$ of the total export of agri-food products in Serbia in the period from 2004 to 2013. The model involved the formation of a set of data from 380 observations that included the export of agri-food products to 38 countries (EU member states, CEFTA member states, Russia, Belarus, Kazakhstan, Switzerland and Turkey). The mentioned authors came to the conclusion that the CEFTA agreement had a significant effect on increasing the 
101 | FOREIGN TRADE IN AGRICULTURAL PRODUCTS BETWEEN THE REPUBLIC OF SERBIA AND THE REPUBLIC OF KAZAKHSTAN - A DECADE SINCE THE SIGNING OF THE FREE TRADE AGREEMENT

export of these products in the signatory countries, by an average of $90.47 \%$, while the Stabilization and Association Agreement also had an impact on increasing the export of agri-food products in the EU member states, by an average of $49.81 \%$. Therefore, Serbia has a double advantage in the export of these products, on the one hand on the global market, and on the other on the markets of EU countries.

\section{QUANTITATIVE INDICATORS OF FOREIGN TRADE IN AGRICULTURAL PRODUCTS BETWEEN THE REPUBLIC OF SERBIA AND THE REPUBLIC OF KAZAKHSTAN}

In the context of the global environment, Stojanović, Mitrović and Petrović (2013) conclude that trade in agri-food products has been constantly declining during the last decade of the twentieth century. The total export of agricultural products from Serbia is mainly directed towards the EU member states and signatories to the CEFTA agreement. In recent years, there has been a symbolic increase in the value of exports of these products to other countries, supported by the signing of free trade agreements with countries such as Russia, Turkey, Kazakhstan and EFTA members. The research conducted by Božić and Nikolić (2013) concluded that from 2005 onwards, Serbia has achieved a positive trade balance of agricultural and food products. This contributed to the agricultural sector becoming one of the few that contribute to balancing the country's foreign trade. However, Vujičić, Ristić and Vujičić (2012) point out that the productivity of agricultural production in Serbia is still at a very low level, while the production structure is not in line with EU standards. This is due to underdeveloped infrastructure in rural areas of the country, modest investment in modernization of agriculture and low intensity of business activities in this sector.

By researching Serbia's export opportunities in relation to the countries of the Caspian Basin, Stojanović and Jovancai (2015) conclude that economic relations between Serbia and Kazakhstan are very underdeveloped. Namely, the mentioned authors note that the value of potential exports of Serbia to the customs territory of Kazakhstan is many times higher in relation to the real value of exports. They state that the value of exports in 2006 was only $\$ 5.4$ million, in 2007 and 2008 about $\$ 11$ million, followed by a decline to $\$ 9.8$ million in 2009, and after that in 2010 exports halved to $\$ 4.6$ million. In the mentioned circumstances, the potential export, obtained by applying the derived 
coefficients and with the existing undeveloped cooperation, amounts to as much as 18.144 million dollars.

In the period from 2012 to 2014, an intensification of cooperation between Serbia and Kazakhstan in the field of exchange of agricultural products could be noticed. The value of exports from Serbia is constantly higher than the value of imports of agricultural products from Kazakhstan. Simić (2020) notes that only 2017 is different because the value of imports exceeded the value of exports. The existence of a surplus of the foreign trade balance of agricultural products is a long-term characteristic of the Serbian economy, with the exception of 2017, when the deficit was realized (Illustration 1).

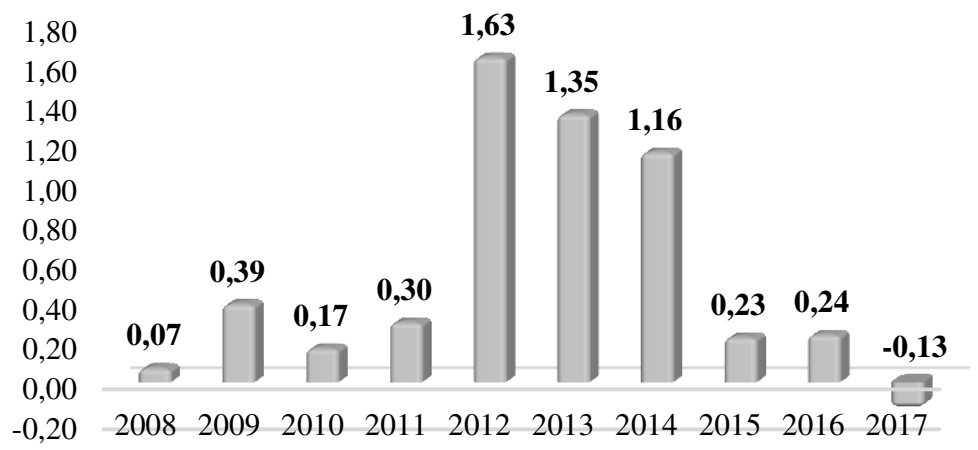

Figure 1. Foreign trade balance of agro-industrial products of the Republic of Serbia with the Republic of Kazakhstan in the period from 2008 to 2017 in millions of USD

Note. Adapted to Simić, M. (2020). Improving the foreign trade of agro-industrial products of the Republic of Serbia with the countries of the Eurasian Economic Union problems and perspectives. Belgrade: Alfa BK Univesity.

Regarding the exchange of agricultural products with Kazakhstan for the period from 2008 to 2017, the average value of net exports indicates that Serbia had a surplus of 0.54 million USD in constant prices. The rate of change in net exports of these products from Serbia to Kazakhstan for the observed period is $1.80 \%$, which indicates that there was almost no real growth in trade between these two countries (Simić, 2020). The coefficient of variation of net exports of agricultural products is $106.36 \%$, and it can be concluded that there are extremely strong variations in foreign trade relations between the analyzed countries, as shown in Figure 1. Researching foreign trade between Serbia and EAEU countries, Simić (2020) concludes that the structure of exports of agricultural products from Serbia to the territory of Kazakhstan is dominated by dairy products, eggs, fruits and vegetables, which together account for close to 
103 | FOREIGN TRADE IN AGRICULTURAL PRODUCTS BETWEEN THE REPUBLIC OF SERBIA AND THE REPUBLIC OF KAZAKHSTAN - A DECADE SINCE THE SIGNING OF THE FREE TRADE AGREEMENT

$80 \%$ of total exports. Regading the imports from Kazakhstan to Serbia, the situation is slightly different, dominated by fruits and vegetables with a share of almost $70 \%$. If we add to that the import of fish and fish preparations and the import of cereals from Kazakhstan, it can be concluded that only these three groups of agricultural items make up more than $95 \%$ of the total import of agricultural products from Kazakhstan to Serbia.

In the period before the conclusion of the free trade agreement between Serbia and Kazakhstan, foreign trade in agricultural and food products was at an extremely low level with a pronounced dominance of exports of products from Serbia to the customs territory of Kazakhstan (Table 3).

Table 3

Export and import of agrifood products between the Republic of Serbia and the Republic of Kazakhstan ih thousands of USD according to selected SITC sections before concluding a free trade agreement (from 2004 to 2009)

\begin{tabular}{|c|l|l|l|l|l|l|l|}
\hline $\begin{array}{c}\text { SITC } \\
\text { divisions }\end{array}$ & $\begin{array}{c}\text { Export/ } \\
\text { Import }\end{array}$ & $\mathbf{2 0 0 4}$ & $\mathbf{2 0 0 5}$ & $\mathbf{2 0 0 6}$ & $\mathbf{2 0 0 7}$ & $\mathbf{2 0 0 8}$ & $\mathbf{2 0 0 9}$ \\
\hline $\mathbf{0 1}$ & Export & & 34,3 & & & & \\
\hline $\mathbf{0 2}$ & Export & & & & & & 333,7 \\
\hline $\mathbf{0 3}$ & Export & & 17,7 & & & & \\
\hline $\mathbf{0 4}$ & Export & 64,3 & 79,6 & 180,7 & 176,7 & 40,0 & \\
\hline $\mathbf{0 5}$ & Import & $\mathbf{1 3 , 7}$ & & & & & \\
\hline $\mathbf{0 6}$ & Export & & & & & 2,5 & \\
\hline $\mathbf{0 7}$ & Export & & & & & 1,3 & \\
\hline $\mathbf{0 9}$ & Export & & & & 77,1 & 39,9 & \\
\hline $\mathbf{1 1}$ & Export & 1,9 & & & & & \\
\hline
\end{tabular}

Note. Adapted according to data of Statistical Office of the Republic of Serbia.

Legend: 01 - Meat and meat preparations; 02 - Dairy products and bird eggs; 03 - Fish, crustaceans, molluscs and aquatic invertrebrates (preparations thereof); 04 - Cereals and cereal preparations; 05 - Vegetables and fruit; 06 - Sugar, sugar preparations and honey; 07 - Coffe, tea, cocoa, spice and manufactures thereof; 09 - Miscellaneous edible products and preparations; 11 - Beverages.

In the period from 2004 to 2008 , cereals and cereal preparations were exported every year with uneven intensity. In 2006, the export of these products reached 
its maximum, but that year cereal and cereal preparations was the only export agricultural item from Serbia.

During 2009, the export of agricultural and food products from Serbia reached a maximum value of 333.7 thousand USD, thanks to only one section of dairy products and bird eggs. In addition to cereals, beverages were exported in 2004, then meat and meat preparations and fish in 2005, various products for nutrition in 2007, and sugar, sugar preparations and honey as well as coffee, tea, spices and manufacture thereof during 2008.

Table 4

Export and import of agri-food products between the Republic of Serbia and the Republic of Kazakhstan ih thousands of USD according to selected SITC sections after concluding a free trade agreement (from 2010 to 2019)

\begin{tabular}{|c|c|c|c|c|c|c|c|c|c|c|c|}
\hline U. & 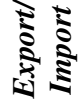 & 응 & $\overline{\bar{ন}}$ & 국 & 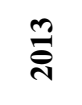 & $\underset{\text { ন্}}{\mathbb{N}}$ & $\frac{n}{8}$ & $\stackrel{0}{\stackrel{\sim}{*}}$ & 곡 & $\stackrel{\infty}{\stackrel{\sim}{\sim}}$ & 를 \\
\hline \multirow[t]{2}{*}{00} & Exp. & & & & & 98,0 & 0,3 & & & 173,7 & \\
\hline & Imp. & & & 0,1 & & & & & & & \\
\hline 01 & Exp. & & & & & 70,0 & 116,9 & & & & \\
\hline 02 & Exp. & 124,4 & 211,0 & 670,0 & 767,9 & 321,1 & & & & 51,6 & \\
\hline 03 & Imp. & & & 6,3 & 10,5 & 6,8 & 1,5 & 10,7 & 49,2 & & 22,0 \\
\hline \multirow[t]{2}{*}{04} & Exp. & & 20,9 & 45,2 & 11,6 & 69,9 & 37,6 & 23,1 & 6,4 & 49,3 & 393,0 \\
\hline & Imp. & & 46,0 & & & & 0,2 & 0,4 & & & \\
\hline \multirow[t]{2}{*}{05} & Exp. & 41,2 & 179,7 & 860,1 & 361,9 & 402,3 & 74,8 & 29,0 & & 11,0 & 46,1 \\
\hline & Imp. & & & & & 33,2 & 37,8 & 31,7 & 202,3 & 233,6 & 174,0 \\
\hline 07 & Exp. & & 5,4 & 7,0 & & & 0,3 & 164,2 & 39,5 & & 71,6 \\
\hline 08 & Exp. & & & & & & & & & 16,1 & \\
\hline \multirow[t]{2}{*}{09} & Exp. & & & & 134,8 & 163,3 & 0,1 & 67,4 & 53,6 & 35,4 & \\
\hline & Imp. & & 2,3 & & 2,3 & 4,5 & & & & & \\
\hline \multirow[t]{2}{*}{11} & Exp. & & & & & & & & 9,1 & 9,1 & 4,8 \\
\hline & Imp. & & & 2,2 & & & & & & & \\
\hline
\end{tabular}

Note. Adapted according to data of Statistical Office of the Republic of Serbia.

Legend: 00 - Live animals other than animals of division 03; 01 - Meat and meat preparations; 02 - Dairy products and bird eggs; 03 - Fish, crustaceans, molluscs and aquatic invertrebrates (preparations thereof); 04 - Cereals and cereal preparations; 05 Vegetables and fruit; 07 - Coffe, tea, cocoa, spice and manufactures thereof; 08 Feeding stuff for animals (not including unmilled cereals); 09 - Miscellaneous edible products and preparations; 11 - Beverages. 
105 | FOREIGN TRADE IN AGRICULTURAL PRODUCTS BETWEEN THE REPUBLIC OF SERBIA AND THE REPUBLIC OF KAZAKHSTAN - A DECADE SINCE THE SIGNING OF THE FREE TRADE AGREEMENT

During the entire six-year period preceding the signing of the free trade agreement between Serbia and Kazakhstan, Serbia imported only fruits and vegetables in a modest value of 13.7 thousand USD (in the same year, exports of agricultural products from Serbia were almost 5 times higher).

After signing the Free Trade Agreement between Serbia and Kazakhstan, the foreign trade exchange become much more intensive, but still below the potential possibilities. As in the previous period, the export of agri-food products dominated over the import. Dairy products and bird eggs, as well as fruits and vegetables became key export items, differently from the period before the signing of the agreement when cereals and cereal preparations were mostly exported. In addition to the above, Serbia exports to Kazakhstan all other agri-food products belonging to certain SITC sections, except for fish, crustaceans and molluscs and preparations there of, which Serbia started importing after signing the Free Trade Agreement.

After the Free Trade Agreement was signed, Serbia started exporting fruits and vegetables to the territory of Kazakhstan. Exports were realized with unequal intensity while maintaining consistency during the ten-year period from the signing of the agreement. The situation is similar with the export of cereals and cereal preparations that have been exported to Kazakhstan every year for the last nine years, but in more modest values in relation to fruits and vegetables. Products that Serbia exclusively exports to Kazakhstan belong to the groups: live animals, meat and meat products, dairy products and bird eggs, coffee, tea, cocoa, spices and manufactures thereof and feeding stuff for animals. Almost the same could be said for various food and beverage products, in which case, in addition to evident exports, symbolic imports from Kazakhstan were also recorded. In the structure of imports of agricultural and food products from Kazakhstan to Serbia, products belonging to two groups clearly stand out: fish, crustaceans, molluscs and preparation thereof, and fruits and vegetables. Import of these products is constant and has been especially intensified after the signing of free trade agreements between these countries.

Additionally, Simić (2020) researched foreign trade between the countries in question, taking into account the classification of products according to SITC sections. She pointed out that in the case of most products, Serbia had a foreign trade surplus, while the deficit was manifested only in the third section (fish, crustaceans, molluscs and prpartions thereof). In addition, in the period from 2008 to 2017, certain sections with a positive foreign trade balance only had a 
deficit in certain years (e.g. 04 - Cereals and cereal preparations in 2011, 05 Vegetables and fruits in 2017). The mentioned author concludes that the highest level of import-export coverage was achieved within the SITC section: 00 Live animals other than animals of division 03, 09 - Miscellaneous edible products and preparations, 04 - Cereals and cereal preparations 05 - Vegetables and fruits, while the lowest level of coverage was recorded in the case of SITC section 12 -Tobacco and tobacco products, 03 - Fish, crustaceans, molluscs and preparations thereof, 06 - Sugar, sugar preparations and honey and 08 - Feeding stuff for animals (not including unmilled cereals).

\section{CONCLUSION}

By researching the foreign trade exchange between Serbia and Kazakhstan, it can be concluded that in the period from 2004 to 2019, the value of imports from Kazakhstan to Serbia was almost 11 times higher than the value of exports of Serbian products to the customs territory of Kazakhstan. During the observed period, Serbia imported the most mineral fuels from Kazakhstan, the value of which reached as much as $94 \%$ of the value of total imports, while various finished products, including agricultural products, machinery and transport devices, dominated the value of exports. Food and live animals, as a segment of agricultural production, during the observed period had a minimal share in the foreign trade of these countries. Namely, the export of food and live animals from Serbia to the customs territory of Kazakhstan made only $3.5 \%$ of the total export value, while on the other hand the import of the mentioned products from Kazakhstan to Serbia hardly existed, it amounted to $0.04 \%$ of the total import realized among these countries. When comparing the realized values of exports and imports of these products, it has been noticed that the export of food and live animals from Serbia was 7.5 times higher than the value of imports of the same products from Kazakhstan to Serbia.

Based on the conducted analysis, the authors also conclude that the value of total imports from Kazakhstan to Serbia after the signing of the free trade agreement was almost 6 times higher than the value of imports in the period before the signing of the agreement. When it comes to the total value of exports from Serbia to the customs territory of Kazakhstan, the situation is different. Exports were otherwise significantly lower than imports, regardless of the observation period. In the period before the signing of the free trade agreement between the analyzed countries, the value of exports was 7.5 times lower than the value of imports, but despite the fact that the value of total exports after signing the agreement increased 1.9 times, the difference was further deepened so in the period after the signing of the agreement, the value of exports became as much as 22.7 times lower than the value of imports. 
107 | FOREIGN TRADE IN AGRICULTURAL PRODUCTS BETWEEN THE REPUBLIC OF SERBIA AND THE REPUBLIC OF KAZAKHSTAN - A DECADE SINCE THE SIGNING OF THE FREE TRADE AGREEMENT

In the current circumstances, the agricultural sector of the Republic of Serbia provides a significant contribution to the value of GDP, affects employment and job creation. With adequate use of available natural resources, in the future we can expect growth in productivity and competitiveness of the agricultural sector. Given that EU membership is one of the goals that Serbia strives to achieve, according to Zekić and Matkovski (2014), a complementary agricultural policy and the growth of agricultural competitiveness will be a fundamental imperative of national policy in the field of agriculture. In the period before the conclusion of the free trade agreement between Serbia and Kazakhstan, the foreign trade of agri-food products was at an extremely low level with a pronounced dominance of exports of products from Serbia to the customs territory of Kazakhstan. Cereals and cereal preparations were mainly exported, followed by dairy products and bird eggs, and to a lesser extent by beverages, followed by meat and meat preparations and fish, then sugar, sugar preparations and honey as well as coffee, tea, spices and manufactures thereof. In the period that preceded the signing of the free trade agreement, Serbia only imported fruits and vegetables from Kazakhstan, and in a very modest value.

After the signing of the free trade agreement between Serbia and Kazakhstan, the foreign trade exchange has become much more intensive, but it is still below the potential possibilities, with the key feature of the dominance of the export of agricultural and food products over the import. In the last decade, most dairy products and bird eggs were exported from Serbia, as well as fruits and vegetables, the export of which began only after the signing of the agreement. As in the previous period, cereals and cereal preparations were exported from Serbia, but in more modest values in relation to fruits and vegetables. In the structure of imports of agricultural and food products from Kazakhstan to Serbia, products belonging to two groups clearly stand out: fish, crustaceans, molluscs and preparations thereof, and fruits and vegetables. Import of these products is constant and has been especially intensified after the signing of free trade agreements between these countries.

Regardless of the fact that after the signing of the free trade agreement between Serbia and Kazakhstan, the foreign trade exchange has become more intensive, it is certainly still below the real possibilities of the economies of these countries as well as below the potential possibilities provided by the agreement itself. In Serbia, the available funds would be most effectively directed to new investments in the agricultural sector, then to infrastructure projects in rural 
areas of Serbia, encouraging intensive and export-oriented agricultural production, as well as the development of sustainable agriculture (Kuzman, Djurić, Mitrović and Prodanović, 2017). Future reforms of the agricultural policy of the Republic of Serbia should include a long-term and clear strategy for the export of agricultural products to the market of Kazakhstan, as part of the EAEU market. Improving the competitiveness of agricultural products of Serbian companies in the mentioned market is of great importance for stimulating foreign trade. In this context, Drucker (1993) points out that all export products that enjoy success have a clear differentiation. Their price is set in a competitive way, but none of them is sold mainly because of the price but because they provide high "added value". In addition, Serbian export companies must have a competitive advantage in the application of appropriate sales channels, while respecting optimal deadlines and other non-traditional marketing tools.

\section{REFERENCES}

Baier, S., L., \& Bergstrand, J., H. (2007). Do free trade agreements actually increase members' international trade? Journal of International Economics, 71, 72-95.

Bartlett, W. (2009). Regional integration and free-trade agreements in the Balkans: opportunities, obstacles and policy issues. Economic Change and Restructuring, 42(1-2), 25-46.

Bjelic, P., \& Dragutinović Mitrović, R. (2012). The effects of competing trade regimes on bilateral trade flows: case of Serbia. Zbornik radova Ekonomskog fakulteta u Rijeci, časopis za ekonomsku teoriju i praksuProceedings of Rijeka Faculty of Economics, Journal of Economics and Business, 30(2), 267-294.

Bogdanov, N., \& Rodić, V. (2014). Agriculture and agricultural policy in Serbia. Agricultural policy and European integration in Southeastern Europe, 153-171.

Bojnec Š. (2001). Trade and Revealed Comparative Advantage Measures (Regional and Central and East European Agricultural Trade). Eastern European Economics, 39(1), 72-98.

Bozduman, E. T., \& Erkan, B. (2019). Sectoral Competitive Advantages in Kazakhstan's Foreign Trade as a Rising Star of Central Asia. In 7th SCF International Conference on "The Future of the European Union and TurkeyEuropean Union Relations (160-168). Turkey: Usak University. 
109 | FOREIGN TRADE IN AGRICULTURAL PRODUCTS BETWEEN THE REPUBLIC OF SERBIA AND THE REPUBLIC OF KAZAKHSTAN - A DECADE SINCE THE SIGNING OF THE FREE TRADE AGREEMENT

Božić, D., \& Nikolić, M. M. (2013). Regional analysis of agricultural and food trade of Serbia (No. 710-2016-48489).

Cheng, L. K., \& Kwan, Y. K. (2000). What are the determinants of the location of foreign direct investment? The Chinese experience. Journal of international economics, 51(2), 379-400.

Drucker, P. F. (1993). Managing for the Future. Routledge.

Đukanović, D., \& Gajić, D. (2012). Evroazijske bezbednosne integracije i bezbednost Balkana i Srbije. Medunarodni Problemi, 64(1).

Grandov, Z., Stankov, B., \& Roganović, M. (2014). Uporedna analiza faktora koji podstiču inostrane investitore na direktna ulaganja u Srbiji i Rumuniji. Škola biznisa, 2, 141-169.

Imamverdiyev, N. (2017). Essays on trade patterns across South Caucasus and Central Asia and the role of Kazakhstan, Russia and Ukraine in the global wheat market (Doctoral Thesis). Universitäts- und Landesbibliothek Sachsen-Anhalt.

Imanberdiev, B. D., Kasimov, S. M., \& Turginbaeva, A. N. (2011). The Influence of Technological Advantages on the Economic Development of Kazakhstan. International Journal of Applied and Fundamental Research, (2), 3-9.

International Agrements. 11/2010. Law on confirmation of the Free Trade Agreement between the Government of the Republic of Serbia and the Government of the Republic of Kazakhstan. Republic of Serbia: Official Gazette.

Jelisavac Trošić, S., Stojanović-Višić, B., \& Petrović, V. (2018). New opportunities for further improvement of economic cooperation between Serbia and China. The Review of International Affairs, 69, 21-35.

Knežević, B., \& Pavlović, S. (2014). Savremeni procesi evroazijskih ekonomskih integracija [Contemporary Processes of Eurasian Economic Integration]. Međunarodna Politika, 1155-1156.

Kunekova, A. (2015). The Role of Internationaş Agreements and Impact of "The Customs Union" On The Kazakhstan's Economic Growth. Eskişehir: 
Anadolu Üniversitesi Sosyal Bilimler Enstitüsü Yayınlanmamış Yüksek Lisans Tezi.

Kuzman, B., Djurić, K., Mitrović, L., \& Prodanović, R. (2017). Agricultural budget and agriculture development in Republic of Serbia. Economics of Agriculture, 64(2), 515-531.

Kuzmanović, M., \& Sanfey, P. (2014). Diagnosing growth constraints in south-eastern Europe: The case of Serbia (No. 167). Working Paper.

Lapenko, M. (2018). ЕАЭС: пространство экономической интеграчии : учеб.- метод. материаль. Москва: Российский совет по международным делам.

Matkovski, B., Lovre, K., \& Zekić, S. (2017). The foreign trade liberalization and export of agri-food products of Serbia. Agricultural Economics, 63(7), 331-345.

Miljković, I., B. (2018). Economic Cooperation Constraints and Potentials. Eurasian Journal of Business and Economics, 11(22), 105-121.

Nordås, H. K., Pinali, E., \& Grosso, M. G. (2006). Logistics and time as a trade barrier. OECED Trade Policy papers, No. 35

Rapaić, S., \& Dabić, D. (2013). Spoljnotrgovinski aspekti pristupanja Republike Srbije Evropskoj uniji. Međunarodni problemi, 65, 341-364.

RAS (Development Agency of Serbia). Invest in Serbia Agri-Food. Belgrade.

Stankov, B., Roganović, M., \& Marjanski-Lazić, S. (2016). Attractiveness of Serbian retail industry for foreign investors with reference to the company Delhaize Group. Škola biznisa, (2), 47-68.

Stankov, B., Markov, J., \& Milošević, I. (2017). FDI by economic activities and investment incentives in Bulgaria and Serbia. Management: Journal of Sustainable Business and Management Solutions in Emerging Economies, 20(77), 61-69.

Stankov, B. (2017). Panel analiza stranih direktnih investicija $i$ konkurentnosti $u$ evropskim zemljama $u$ nastajanju $i$ razvoju (Doktorska disertacija). Novi Sad: Fakultet za ekonomiju i inženjerski menadžment.

Statistical Office of the Republic of Serbia. https://www.stat.gov.rs/

Šabić, D., Vujadinović, S., Milinčić, M., Golić, R., Stojković, S., Joksimović, M., ... \& Dimitrijević, D. (2012). The impact of FDI on the 
111 | FOREIGN TRADE IN AGRICULTURAL PRODUCTS BETWEEN THE REPUBLIC OF SERBIA AND THE REPUBLIC OF KAZAKHSTAN - A DECADE SINCE THE SIGNING OF THE FREE TRADE AGREEMENT

transitional economy in Serbia-changes and challenges. Acta Polytechnica Hungarica, 9(3), 65-84.

Simić, M. (2020). Unapređenje spoljnotrgovinske razmene agroindustrijskih proizvoda Republike Srbije sa zemljama Evroazijskog ekonomskog saveza - problemi i perspektive. (Doktorska disertacija). Beograd: Alfa BK Univerzitet.

Stanojević, N., \& Jovancai, A. (2015). Diversification of Serbia's Export Markets-Potentials for Export to the Countries of Caspian Basin. Economic Themes, 53(2), 278-297.

Stojanovic, Z., Mitrovic, R. D., \& Petrovic, I. P. (2013). Serbia's Food Trade Competitiveness and PTAS in the EU Integration Process (No. 710-201648479).

Van Berkum, S., \& Bogdanov, N. (2012). Serbia on the road to EU accession. Consequences for agricultural policy and the agri-food chain. Serbia on the road to EU accession. Consequences for agricultural policy and the agri-food chain.

Vasily, E., \& Ivolga, A. (2013). New developments in russia-eu trade with agricultural goods: influences of trade integration. Economics of Agriculture, 60(2), 299-308.

Vujicic, M., Ristic, L., \& Vujicic, M. (2012). European integration and rural development policy of the Republic of Serbia and West Balkan countries. Bulgarian journal of agricultural science, 18(4), 519-530.

Zekić, S., \& Matkovski, B. (2014). New CAP reform and Serbian agriculture. Sustainable agriculture and rural development in terms of the republic of Serbia strategic goals realization within the Danube region. Rural development and (un) limited resources, 1095.

Delivered: 15.06 .2020$.

Accepted: 02.12.2020. 